\title{
Towards Competence-based Practices in Vocational Education - What Will the Process Require from Teacher Education and Teacher Identities?
}

\author{
SÄde-Pirkko Nissil ${ }^{* 1}$, Asko KarJalainen ${ }^{2}$, MarJa KoukKari ${ }^{3}$, AND \\ PirkKo KePANEN ${ }^{4}$
}

$\approx$ Competence-based education refers to the integration of knowledge, skills, attitudes and interactivity as the intended outcomes of learning. It makes use of lifelong learning and lifelike tasks in realistic settings and requires the cooperation of teachers. This research was prompted by the desire to explain why collegial cooperation often seems to be problematic in schools and universities. Are there certain social structures or behavioural patterns that influence the cooperative culture in teacher communities? The research material was collected in 2013 and 2014 in Oulu, Finland. The target groups were both newly qualified and experienced vocational teachers at all educational levels $(\mathrm{N}=30)$. The data collection methods were open questions in interviews and questionnaires. The research approach and analysis methods were qualitative. The theoretical background is in humanistic-cognitive and experiential learning as well as in dynamic epistemic conceptions. The findings show that the prevailing model in teacher communities is individualistic, disciplinedivided and course-based, especially among older teachers. The obstacles refer to teachers' self-image and a deeply rooted fear of criticism or revelation of incompetence. The promoters of cooperation were connected to the changing practices and desire of sharing with colleagues.

Keywords: attitude, cooperation, learning in work places, life-long and life-wide learning, professional development

$1 \quad{ }^{\star}$ Corresponding Author. Oulu University of Applied Sciences, School of Vocational Teacher Education, Oulu, Finland; sade-pirkko.nissila@oamk.fi

2 Oulu University of Applied Sciences, School of Vocational Teacher Education, Oulu, Finland

3 Oulu University of Applied Sciences, School of Vocational Teacher Education, Oulu, Finland

4 Oulu University of Applied Sciences, School of Vocational Teacher Education, Oulu, Finland 


\title{
Proti kompetenčnemu sistemu poklicnega izobraževanja - kaj bo proces zahteval od izobraževanja učiteljev in učiteljevih vlog?
}

\author{
SÄde-Pirkko Nissil ${ }^{*}$, Asko Karjalainen, Marja Koukkari In \\ PiRKKo KePANEN
}

Kompetenčni sistem izobraževanja pomeni, da so v predvidene dosežke učenja integrirani znanje, spretnosti, odnos in interaktivnost. Naslanja se na vseživljenjsko izobraževanje in realistične naloge v realnih situacijah ter zahteva sodelovanje učiteljev. Raziskavo je spodbudila želja ugotoviti, zakaj se kolegialno sodelovanje $\mathrm{v}$ šolah in na univerzah pogosto zdi problematično. Ali obstajajo določene socialne strukture ali vzorci obnašanja, ki vplivajo na sodelovalno kulturo v učiteljskih skupnostih? Podatki so bili zbrani v letih 2013 in 2014 v Ouluju na Finskem. Ciljna skupina so bili učitelji začetniki in tudi izkušeni učitelji v poklicnem izobraževanju na vseh stopnjah izobraževanja $(\mathrm{N}=30)$. Zbiranje podatkov je potekalo $\mathrm{z}$ intervjuvanjem in anketiranjem $\mathrm{z}$ odprtimi vprašanji. Raziskovalni pristop je bil kvalitativni. Teoretična ozadja predstavljajo humanistično-kognitivno in izkustveno učenje pa tudi dinamični epistemološki koncepti. Rezultati so pokazali, da med učitelji prevladuje individualističen model, razdeljen na discipline in osnovan na učnem načrtu, še posebej med starejšimi učitelji. Ovire pri sodelovanju so predvsem učiteljeva samopodoba ter globoko ukoreninjen strah pred kritiko in razkritjem nekompetentnosti. Spodbujevalci sodelovanja so bili povezani s spreminjanjem prakse in z željo po izmenjavi med sodelavci.

Ključne besede: stališča, sodelovanje, učenje na delovnem mestu, vseživljenjsko in celostno učenje, profesionalni razvoj 


\section{Introduction: Competence-based education system}

Competence-based education is becoming increasingly dominant in European countries and Australia (Clarke \& Winch, 2007; De Bruijn, 2004). In Finland it began in 1994 in secondary vocational education. Since the European Bologna process was launched in 1999, it has become a common aim of all tertiary education. The term "competence-based education" seems to cover various ideas: teachers taking into account the changes in the education system, a greater access to A-levels, the students' heterogeneity, the inclusion of children with special needs as well as the growing autonomy for junior high school and grammar school. Consequently, teachers' roles and work as previously defined have changed. Nowadays, there is an emphasis on teacher autonomy in order to adapt oneself to the local contexts. (FNBE, 2014.)

One meaning seems to be shared: it refers to the integration of knowledge, skills and attitudes as the intended outcomes of learning, relying on lifelong learning and lifelike tasks in realistic settings. The theoretical background is in humanistic-cognitive and experiential learning as well as in dynamic epistemic conception. All forms of competence are seen important, and should be identified and recognized. Assessment is supportive to professional development and focuses on professional performances in authentic contexts. (FNBE, 2014; EU, Bologna Declaration, 1999.)

\section{Competence-based system in adult and vocational education}

In adult and vocational education in Finland, a competence-based education system has been established. Vocational upper secondary, further vocational and specialist vocational qualifications can be completed through competence-based qualifications or through vocational upper secondary education and training. A competence-based qualification is completed by demonstrating vocational skills, as stipulated in competence-based qualification requirements, in workplaces in authentic work tasks.

Key principles of the system in vocational training include 1) tripartite cooperation between employers, employees and teachers when planning, arranging and assessing competence-based qualifications; 2) independence of the manner in which the skills were acquired; 3) completion of the qualification/ qualification module by demonstrating the skills at competence tests; and 4) personalization. Depending on the subject covered, a vocational upper secondary qualification attained in the form of a competence-based qualification (nominal extent 120 credits) or a corresponding earlier qualification 
confer general eligibility for further studies at universities of applied sciences in the corresponding field. From there, they can continue in science universities. (Heiskanen \& Sairanen, 2013.)

Competence-based vocational education covers various ideas and practices. Authentic and functional learning is supported by learning underlying knowledge and training in specific skills. Assessment is supportive to professional development and focuses on the quality of performances in authentic contexts. (De Brujin, 2012.) Teachers are expected to be adaptive coaches and role models. Team teaching is seen as highly relevant (Biemans et al., 2009; Billet, 2001; Nijhof et al., 2002). Being a role model either in school or in the workplace is often perceived as being demanding (Aarkrog, 2005; Griffith \& Guile, 2003; Tynjälä, 2008; Van der Pol et al., 2011; Van Schaik et al., 2011).

Earlier research reports described how teachers in competence-based vocational education changed their teaching practice (e.g. de Bruijin \& Van Kleef, 2006). The studies concentrated on pre-vocational and senior secondary vocational education in the formal education system in the Netherlands.

De Brujin's study (2012) revealed four main characteristics and guidance features in competence-based education. They were 1) powerful learning environments (adaptivity \& expansion of tasks), 2) proven teaching methods and experiential ones in a new educational concept (flexible use), 3) professional identity learning (modelling, coaching) and 4) self-regulation (monitoring, guiding, scaffolding). (De Brujin, 2012, pp. 644-655.) Professional identity formation of a teacher was seen as crucial to connecting the framework for the contents and for teaching and learning activities that make up these courses. No deeper analyses of self-concept, self-efficacy, and relationships with colleagues and students were made in De Brujin's study.

\section{Competence-based teacher education}

Competence-based teacher education has been a controversial issue in many countries. What is seen positive is that the clear learning objectives clarify the aims of the training program to be realized. It can be a tool for professional development to the extent that it helps student teachers, teacher educators, and all teachers to formulate goals, develop self-assessment and reflection upon practice (Koster et al., 2008). A competence-based approach also makes clear the difficulty of high quality performance in teaching. As such, it contributes to the demystification of teaching and opposes the charismatic image of a good teacher whose competence results from his/ her natural talent (Connell, 2009; Whitty \& Wilmott, 1991).

In contrast, detailed lists of skills to be achieved may lead to a fragmentary 
approach to teaching in which the teacher's action seems to be an inconsistent sum of given skills. Separate skills do not guarantee efficient behaviour in professional contexts. Curricula should aim at holistic views. Teachers are part of the school and teachers' community; therefore, performing well also depends on how colleagues are doing. (Connell, 2009; Korthagen, 2004; Pantic \& Wubbels, 2010; Cosnefroy \& Buhot, 2013.) Teachers are likely to face problems that cannot be solved solely with technical skills. Values, ethical commitment, and personality have an impact on teachers' decision-making and their choice of technical skills to be used.

Although several pilot experiments are promoted in the Oulu School of Vocational Teacher Education (SVTE) (Karjalainen \& Nissilä, 20o8; Länsitie \& Kepanen, 2014), this presentation does not primarily concentrate on pre-service teacher education. The main target is to determine what kinds of readiness qualified academic, vocational in-service teachers need when encountering the challenges of the new system.

\section{Workplace learning in competence-based teacher communities}

Competence-based education and especially teachers' pre-service and in-service education imply that academic and vocational knowledge are insufficient to support a teacher's work. To bridge the gap between theory and practice, competence-based education reassesses the roles of school and workplace. Within this framework, both workplace and on-the-job learning play an overriding role. (Struyven \& Meyst, 2010.)

Tynjäläs (2008) framework for workplace learning made a distinction between three basic learning modes evident in the workplace: 1) incidental and informal learning that takes place as a side effect of work; 2) intentional, but non-formal learning activities related to work; and 3) formal on-the-job learning. Incidental/ implicit learning produces tacit knowledge, while non-formal learning takes place outside the training program but can be planned and produce explicit knowledge. For example, peer group mentoring at school is a kind of formal on-the-job learning, while interacting with colleagues or learning by oneself from the teaching experiences takes place outside the training program. (Tynjälä, 2008.) Eraut (2007) sees learning as a by-product of working with colleagues or unplanned observations of them.

It could be argued that research on workplace learning in vocational education/ training should adopt an extensive view including learning by oneself, learning with/ from colleagues and investigating how these modes and interactions complement each other. 


\section{About teacher competences and qualifications in vocational contexts in Finland}

Teachers in secondary and tertiary vocational education in Finland are intended not only to teach a subject with high pedagogical standards but, particularly at the secondary level, also identify and help students with emotional and behavioural difficulties, to challenge bullying, or to promote communication with family. Caring for students is part of teacher's work. The cognitive skills comprise knowledge, skills, values and attitudes and capability to use them in certain contexts/ situations. Knowledge dimensions can be expressed by factual, conceptual, procedural and metacognitive knowledge which are to lead to understanding. (Krathwohl, 2002.) Teachers also need active work life contacts and a wide orientation in their trades and professions. This is the background of the teachers who formed the research group in this study.

\section{The research: purpose, data collection, and analysing methods}

This research will be targeted to secondary and tertiary vocational teachers' cooperation practices and teachers' willingness, ability and skills for joint working. It emphasizes the necessity to identify the obstacles of cooperation for promoting collaborative teaching in competence-based teaching programs.

More specifically this research attempts to delve deeper to teachers' mind sets and discover how teachers experience the cooperation needed in competence-based approaches, what are the emotions and attitudes connected to the change and how teachers see themselves amidst the change. How do teachers share their ideas, methods and materials? How do they ask for help from colleagues inside and outside their nearest work environment? Do vocational teachers feel dependence, trust, suspicion or even envy towards their colleagues in their daily work and professional issues?

The research material was collected in Oulu University of Applied Sciences, in the SVTE by open questions in interviews and questionnaires. The target group was newly qualified and experienced vocational teachers $(\mathrm{N}=30)$. The research approach was phenomenographic; the analysis methods were qualitative.

The research questions were:

1. What are vocational teachers' conceptions of cooperation in their work contexts?

2. What obstacles and promoters of cooperation do the teachers identify in their work contexts? 
3. What are teachers' experiences of mutual relationships in their work communities?

4. What attitudes and intentions seem to guide teachers' cooperation at work?

\section{Findings}

The answers revealed that the situation was complex. The prevailing model of everyday behaviour in teaching communities seems to be partly proactive, partly reactive going back to earlier adopted action models.

\section{General observations}

Although efforts have been made in Finland since 1994 to promote competence-based vocational education, change remains a work in process. In secondary education skills demonstrations, scoring of competences and concentrating on core skills have already been adopted. In higher education, change has been slow to start. Subject-oriented thinking in teaching still prevails.

In their work communities, all respondents experienced that there were actions and attitudes typical of the culture of sharing, but sincere cooperation was not taken for granted. The teachers experienced that sharing and collaboration were fully dependent on the personal characteristics and relationships between the teachers in the work community. Although teachers are known to work well together, they do not necessarily share their expertise with others: for instance, by voluntarily giving their teaching material to colleagues. All respondents said that helping the colleagues is one of the teacher's duties; however, it is not always possible for many reasons.

It seems that in educational communities there are no "rules of the game" or action models for mutual responsibility for developing teaching. Teachers would especially need advice how to share mental and material resources to benefit the initiation of new teachers. The lack of collective responsibility was apparent: the mentality of the teachers was to keep teaching material only in personal usage because it had required much individual work. Temporary lecturers also took their teaching materials with them when leaving the post.

Team teaching was temporary in all work places within the study. If it occurred, it usually took place between the assigned teachers. Nearly all respondents emphasized that team teaching required additional resources, and for that reason it was not discussed as a pedagogical alternative. The general economic depression of society was observed in educational organizations according to the next respondent: 
Now we only go forward within these strict economic limitations, and we don't have time to develop anything.

The statement sends a message of nonchalance, perhaps also sadness and defensiveness.

In the following, learning with colleagues will first be examined, and then the obstacles and promoters of cooperation studied. Following that, a deeper analysis and efforts will be made to interpret the meanings expressed from the points of view of communication, leadership, and management.

\section{Learning with colleagues}

A major criticism of competence-based teaching is directed towards cooperation and sharing. Teaching activities have historically been an individual enterprise in Finland. The capacity to deploy specific competences depending on the context is a critical meta-competence. However, teachers are likely to face problems that cannot be solved solely by technical skills. Values and ethical commitment as well as personality have an impact on teachers' pedagogical thinking and decision-making. Competence-based teaching requires collective teaching work:

You can ask for help from you colleague if you need it, helping is a part of good manners. Helping must not be continuous, and it shall not resemble manipulation.

Competence-based education values the role of school and workplace in the learning process of both the students and the staff. Within this framework, the implementation of the curriculum and the whole system play an important role:

The course material bought from the publisher is freely at use, the files are changed, and with acute problems you can always ask for help.

Learning with colleagues occurs through discussions, observation or joint activity, i.e. by sharing experiences and materials or collaborating in a project. Teachers can improve pedagogical competencies by becoming consciously aware of the consequences of their actions and by adjusting their practices. For that reason, mentoring is one important dimension of workplace learning. Interaction with colleagues in informal contexts is also a major learning mode to gain access to practical knowledge:

In small teams, cooperation is a daily practice. Bigger communities do not develop, since cooperation is scarce. New teachers need encouraging and mentoring to support their skills.

Continuing learning is a social process by which newcomers and experienced colleagues can acquire skills necessary in the community of practice. (Lave \& Wenger, 1991.)

Teaching competencies include communicative interaction and listening 
skills. They imply the ability to listen to another person, identify his or her feelings and thoughts and fit to his or her specific needs. As a consequence of tight economic pressure and time frames, there is little room for cross-curricular teaching. Teachers do not work together so much as would be useful, and this fact possibly explains why teachers, especially in crowded teacher rooms, do not know each other well enough and are not entirely active in sharing their methods and teaching material with others.

\section{Obstacles to cooperation}

The findings of this research concerning the obstacles of cooperation can be viewed more closely and listed as the fears of the teachers which were numerous.

1. The fear of revealing personal incompetence to the colleague(s) is deeply rooted.

One reason for that can be the old system of teacher training in Finland. In teaching practice periods, trainees were trained by focusing on the mistakes they made and the defects they had. This frequently resulted in low self-esteem. Generations of teachers have gone through their careers by believing that they are not good enough.

Sharing the material prepared by the teacher is prevented by selfishness and the revelation of the sources of the material. Fearing for the borrower entitling the material to him/herself. Fear for the critique of the material by colleagues.

Along with the new generation of teacher educators, this culture will hopefully be dying off.

A teacher's personality, especially at the beginning of one's career, needs strong and caring support. Although the teacher's role has greatly changed, and the work is defined through joint action, the teacher is exposed to public criticism. 2. The fear of the revelation of the defects in the teaching material is connected to the previous fear.

It is not only a teacher's appearing and acting, but also writing, collecting material, drawing conclusions and preparing the material to be presented, which is important to the author:

I have prepared this myself; nobody has paid for it.

The material is a reflection of me.

Consequently, criticism hurts the author personally.

3. The fear of being evaluated by the colleague in team teaching and getting negative feedback.

This fear is again connected to the teachers' weak self-image and their lacking self-efficacy. They find it difficult to hear "the truth" (as they express it), 
and they interpret even positive or neutral remarks in a negative way. The trust appeared to be the key word:

You can trust in some people better than others, especially in substance matter knowledge.

4. The fear of the colleague(s) rewriting the teaching material and spoiling the work of the owners is one way to hurt the author's autonomy.

According to the respondents, the rewriters can misunderstand something and lead the contents to a wrong direction, they can cut the presentation with negative consequences. Such fears are common still: nobody's material can be used without changes or explanations. The rewriters have to create something that is suitable to their ways of teaching. This is again another point of fear and envy: the rewriters are benefitting from another's work.

5. The fear of allowing the colleague(s) take a smaller load of the teaching burden: I don't give out of my own resource bank.

In my work community, there is a teacher who prepares teaching material very pedantically and carefully. He will never give his slides to anyone, but chooses between them and gives something like a paper version so that everybody has to do something him/herself.

One of the respondents complained that there are teachers who always ask for help from others without ever taking responsibility for actively promoting teaching themselves.

This fear is evidently connected to envy. Teachers are often very strict with the time resources that they are given, and they do not want to exceed the allotted schedule without extra pay. Moreover, the question is deeper than time resources: it is a kind of misconception of measuring teacher efficiency with a watch in the hand. The profession should, however, be a global effort.

6. The fear of the colleague(s) taking the ownership of the knowledge produced by its author.

It is as if knowledge should be untouched as if it were not common capital. Clarifying shared aims and finding time for joint discussions might help in overcoming this misconception.

7. The fear of going beyond the author's range of expertise.

Teachers sometimes have the desire to be seen as the only or the main experts in their specialist areas and feel hurt if somebody wants to prove him/ herself in his or her "territories". A joint effort, however, might be a much more fruitful approach. If there are teachers who find common interests despite the fact that one of the group is a greater expert that the other(s), it should be taken as a benefit. However, it can lead to the next fear.

8. The fear of one's task becoming unnecessary, when the colleagues share 
the material and can teach the expertise without the presence of the original author.

The fear of losing one's status or work has become common in these times of uncertain economic resources. Nevertheless, teachers should fight as one united front, not attacking each other.

9. The fear of breaking the copyright, for instance, releasing the material on a public network is a subject of real concern.

The problem can be easily solved by defining the rights of the material usage. Furthermore, general discussion about copyrights and citation referencing at work is usually necessary. Such information should be forwarded to students as well.

10. The administration was afraid of team teaching taking too many resourc-

es (time and money).

In part, this fear is based on a misconception. Nowadays, most secondary and all tertiary teachers have a system of an annual quota of working hours. Team teaching can be organized within this framework. The greatest obstacle is unwilling teachers who are afraid of unknown, untested solutions.

\section{The promoters of cooperation}

The research has shown that professional development is a contextualized process that depends on school culture and school management (cf. Flores, 2004; Flores \& Day, 2006; Kardos et al., 2001).

The results highlight the prevailing role of colleagues, which is the learning mode that comes first in teachers' conceptions when evaluating their teaching competencies. The researchers refer to informal mentoring to depict planned and unplanned interaction and cooperation with colleagues in work places and to support the development of teachers' positive self-images and identity.

In order to make learning with colleagues an effective learning mode, the schools should provide collaboration opportunities for teachers (also Kardos \& Johnson, 2007; Kardos et al., 2001). The schools should tend to favour a shared responsibility and responsiveness to each other's specific needs. In other words, they should attempt to create integrated professional culture. School leadership is important in creating the conditions for the school and its teachers. Successful leaders share common features, such as providing opportunities for teachers to develop a shared vision of the school's mission and goals, strengthening the sense of self-efficacy among teachers, developing a close working relationship with staff members and securing adequate resources (Flores, 2004). In contrast, in older professional cultures, the norms of privacy prevailed with little room for exchanges on professional issues. (Flores et al., 2006; Kardos et al., 2001).

A closer examination of the findings of collaboration promoters leads to 
the following conclusions/factors:

1. The first is the general atmosphere to which the staff is socialized.

A positive working context promotes open and trusted relationships between colleagues. They can experience becoming appreciated and encountered caringly:

In open and discussing atmosphere [...] all have shared aims. Openness and tolerance are important.

The change of culture: workshops, teamwork, on-the-job learning have given positive experiences.

These experiences prompt collaboration and strive towards shared goals. When a teacher feels that she/he has been helped by others, she/he will also do the same in new situations. When teachers discuss together on the curricula and the affairs connected with them, it motivates cooperation.

2. The second factor is connected to developing expertise.

No one is an expert in the beginning, but in the course of time, in dialogical interaction with others, expertise will develop. The dialogue will also develop team teaching in appreciating the exchange of thoughts and measures: If a conflict arises, we know how to act.

3. The basis of successful team teaching is teachers' self-esteem and competence.

If this is not attained, problems will arise in the work community. Teachers often prefer individual work to cooperation. In this case, the teacher may be fighting with his/ her social emotions (pride, envy, contempt, and shame), feelings that are born along with cultural learning. They need a change of attitudes: The pedagogy of joy deters envy and bullying.

4. In connection with the factors above, a respondent experienced that $c o$ operation is prevented by personal attitudes and dislike of changing old ways of individual acting:

I have tried to get rid of the old ways and have not stayed milling around in them, along with which I feel that the atmosphere has become better, because earlier it was not good.

5. The employer can also obligate the teachers to cooperate. A respondent describes the phenomenon in the following way:

The employer has ordered me into a team that has a clear assignment and, accordingly, it is compulsory to work as a team with others.

6. At the level of feelings, the necessity is connected to the formation of a motivational state that relies on rewards and punishment as motivating factors. At the level of basic feelings, the compulsion to act can bring pleasure, if action is successful. However, it can also bring fear, hatred, 
disgust and sorrow. In order to make teamwork genuinely motivating and pleasant, it should have an inspiring and interesting goal:

There is one team that I belong to, and it is active and has clear aims so that we know why the team has been set up and what is its task, what are its members' roles, what are the responsibilities and authorities. The team has an awesome spirit, and we value each other.

Two major factors behind the findings above appear to be: human relationships at work place and leadership.

You can ask for help from some colleagues, but not from others. You can sense from a person who will help, who won't.

It is easier to ask for help from the ones who are sympathetic. If a person has a fame of being difficult, I don't approach him/ her.

Everybody is busy. - It is rewarding if you can ease someone's burden amidst everyday duties. If you have been wrestling with the same problem and found a solution, you can share it.

Human relationships and school leadership and management are mentioned in all answers. In the following, they will be examined more closely in order to answer the questions 'What is the source of knowledge about my colleagues?' and 'What is the role of leaders and managers in promoting teachers' professional development?'

\section{Human relationships and communication in work contexts}

Collaboration for professional development means sharing power and mutual interaction. It means a change in teacher culture. It is important to reflect individually and collectively about the work place practices, personal experiences, and situations.

It is easier to work as a team with some than others. In principle, a teacher is always individually responsible for teaching (i.e. If your colleague makes mistakes, you will also be responsible for them).

Besides possibly being a collective event, reflection means an interactive process between one's earlier experiences, actions, personal theorizing and understanding theories. Its significance is in making implicit things explicit. (Nissilä, 2013.)

Much knowledge of other people is tacit: although one might gossip about them, he/ she does not often have to put knowledge of people into words unless it is a specific part of one's job. Yet some knowledge provides the basis of unhesitating daily interactions with others. (Horvath et al., 1996.) Knowledge about another person is mainly collected from series of encounters set up for other purposes: only a small percentage of meetings will lead to getting to 
know that person as an objective, most often it is an incidental side effect. The knowledge gathered in this way is not questioned and is not likely to be created under one's critical control. Explicit knowledge can be created through reflection or from other sources, but is not supposed to replace the tacit knowledge that enables one instantly to respond to people one knows. Thus knowledge of other people is taken-for-granted, is self-confirming and includes:

- $\quad$ our encountering with another person, which may be influenced by situational factors;

- most obviously, remembering the long-established events connected to the person in question;

- $\quad$ preconceptions created by earlier encounters, i.e. the sample is not constructed from genuinely independent events;

- $\quad$ personal constructs by people (Kelly, 1955) as the result of their life experiences, which affect people's understanding of those whom they meet. (Eraut, 1994.)

Tacit knowledge continues to influence, because it is available. It is seldom as valid and unbiased as we like to assume.

Communication in schools is another feature to be considered. It can serve purposes other than making knowledge or actions explicit. Learning to talk to students, colleagues or managers may be a semi-conscious process during which the latent functions of the discourse are not revealed and may even remain hidden from qualified professionals. Latent functions may tend to maintaining good relations with colleagues while preserving personal freedom, asserting one's professional prestige and rendering account of it to the administration, keeping managers aware of your actions while keeping the superiors behind your back.

It is not possible to ask for help from the boss spontaneously. You have to make an official request or question. (Otherwise you can appear as unskilled, unknowing)

Among the staff somebody is always excited about something. (Either sincerely or wanting to show off)

It is difficult to talk about envy and bullying. (They belong to the unspoken, tacit area of feelings)

Latent communication tends often to mislead, because implicitly acquired discourse has been developed for that very purpose (Eraut, 1994). Communication is one area that should be analysed to help teachers understand its functions.

Teaching as an ethical practice presupposes self-respect, respect for the others, empathy, and ethics. In work contexts and in continuing education the ability to think and talk about the work situations as well as to analyse 
the sequences of events is supported (Wenger, 1998). It is important to be able to talk about personal experiences without blaming other persons or talking about the feelings without addressing the persons absent.

Teachers' practical theory tends to be experiential and is preserved as tacit knowledge. It has many sources, from biographical events to integrated values. How these sources become integrated into a person is defined by the learning situations and their interpretations. They filter the obtained knowledge to the conceptual frame of teachers (Eraut 1994). The change of conceptions will be conscious, if the process is supported by thinking, reasoning and theoretical knowledge.

\section{Leadership and management}

In the field of education, as in many other institutional contexts, leadership has taken on increased importance in recent years. Harris (2004) writes about transactional leadership, which prevails in educational contexts in challenging circumstances, in which teachers are expected to obey orders without any explanations and are motivated through rewards and punishments. The leadership style is thus strong, directive and revolves around curriculum and instruction. (Harris, 2004.)

Collaboration in my work context is rather weak, since the issues are attended through the leadership and their orders [...] The leaders and support staff determine and decide about everything, there is no democracy, and teachers can't influence things.

In the staff, there are many teachers with over 25 years of work experience. We are joined together by accusing bosses.

There is broad dissatisfaction with focusing too much on the leader as the centre of expertise and authority. Teacher leadership has become the centre of interest as to their accountability for their students' learning achievements. Working in a context characterized as a learning organization offers the greatest opportunity to unlock leadership capacities and capabilities among teachers. (Harris \& Mujis, 2003; Laajala, 2015.)

In transformational leadership, teachers are committed and self-motivated to respond to changes in the long term. Lieberman and Pointer Mace (2009) described the role played by accomplished, experienced teachers in professional learning communities, and the importance that these practitioners made their teaching public and shared. This resulted in the conclusion that the robust, lasting professional development must begin with what teachers know and do, effecting educational reform from inside the educational units. (Lieberman et al., 2009.) 
New teacher professionalism includes mentoring and support in learning and knowing. Team teaching eases the burden of a single teacher. -

School leadership should understand that team teaching does not need more resources than individual teaching. The question is about a different kind of organizing teaching.

Therefore, the whole community can be engaged in the sharing of knowledge that enhances the creation of professional knowledge. The reciprocal dynamics create an environment larger than the task and the individual. It creates a web of relationships and constructs individual and organizational identities. They emerge from a variety of sources depending on the issue or the individuals' expertise and creativity (Harris et al., 2003; Mitchell \& Sackney, 200o). Personal strength goes hand-in-hand with effective collaboration. Personal and group mastery cause each other to thrive in learning organizations. (Nissilä, 2006; Fullan, 1993.)

According to Leithwood and Riehl (2003, p. 6), educational institutions are today undergoing critical changes, and they need the combination of different forms of leadership that involve mobilizing the learning community staff and clients to face and take on the task of changing teaching culture. This also requires harnessing and mobilizing the resources needed to support this process of change (Spillane et al., 2001). Transformational leadership presupposes pedagogical approaches from the administration and the teachers.

\section{Conclusion: teacher identities in the change process}

The findings of this study can be summarized by choosing the most influential obstacles and promoters in teachers' team work and self-efficacy which seemed to be essential in competence-based education.

\section{First, think proactively!}

Teachers are afraid of losing face. They want to hide their problems with student interaction behind their (supposed) expertise. The aspect of development and learning new measures for problematic situations should be proactive. The courage to think proactively is easily lost.

\section{Second, learn to know your colleagues!}

Teachers do not rely on their colleagues. They are afraid of being betrayed, if they are too open on issues that they think belong to their privacy. The only way to fight against this fear is to "open up", preferably in a good team. The better you learn to know your colleagues, the easier it is to be confident. 


\section{Third, listen to your colleagues genuinely!}

Teachers should learn to listen to their colleagues, not only words but also meanings. They should not only rely on the so-called strict talk about professional matters or talk about themselves in a flattering way.

\section{Fourth, balance qualitative and quantitative factors of your work!}

Teachers should not only count the workloads or time resources and compare them. In addition to quantitative factors, there are also qualitative ones that are more difficult and certainly more important to take into account.

\section{Fifth, inform your educational administration of topical work issues!}

Educational administration should observe the right things and take the teachers' fears seriously and find measures to reduce them.

Being able to communicate with others and exert dialogical skills, i.e. speaking and listening, is a core competence of teachers. Experiences are connected to the formation of professional identity. This process needs space and time as well as the feeling of safety and the control of inner and outer anxiety. A professional is able to combine the demands from outside, his/her own expectations of others and his/her ideal self-image which s/he can compare to his/her real selfimage. Professional development is constructed in collegial interaction through individual reflection on conscious wishes and observations. In this autonomous process personal impulses and objectively observed ideal self-image should be balanced. (cf. Nias, 1989; Kelchtermans, 1996, 2009; Little, 1996; Zembylas, 2003.) It will lead to understanding that the issues of collegiality and their impacts on a teacher's self-image should be dealt with in detail hopefully in collegial discussion.

Kelchtermans (1993) has identified five aspects through which teachers' professional identity can be grasped. The first is the vision of oneself as a teacher, i.e. self-image. Second, a vision of oneself is closely connected to valuing and evaluating oneself as a teacher, i.e. to self-esteem, which is connected to and driven by comparisons with others. It can be defined as the result of balancing the self-image and professional norms. The third identity factor, job motivation, includes motives for entering and staying in teaching. Understanding one's tasks as a teacher, task perception, is the fourth factor indicating how teachers define their work. In addition to students and didactical abilities, cooperation with colleagues and situational sense in teaching are also related to this factor. Fifth, future perspectives, i.e. expectations for future work development and evaluation of options and opportunities are also one of the means of grasping teachers' professional selves. These views can be practiced, visualized and illustrated in many pragmatic ways.

In vocational education, teachers' professional lives are twofold: as teachers 
and experts of their vocations/ professions, they are attempting to find ways to include the importance of both aspects in their teaching (Nissilä, 2006). The process of professional development should enable the dialectic of interaction between the forces of autonomy and dependence, of being able to work in an educational system with its constraints and in the field of work life and networks of disciplines and vocations. The dialectic interaction also appears in the attitude to team work and helping colleagues. Sometimes teachers have to be reminded that collaboration benefits both partners. It will hopefully be realized in competence-based programs when they are run throughout vocational and university education.

\section{Discussion}

One of the challenges in the competence-based education system will evidently be personalization. It refers to customer-oriented planning and implementation of guidance, advisory and support measures as well as creating and implementing the bases of required knowing together with colleagues. It requires increased cooperation between teachers and other actors in the field. It also requires supporting teachers' professional development and self-efficacy.

How can the identity of teachers be supported? The present research suggests confirming and validating the novice and experienced teachers' images of self as teachers, acquiring knowledge of students and contexts, experiencing cognitive dissonance and questioning the appropriateness of personal images and beliefs and finally acquiring instructional practices. Up-to-date knowledge of vocational secondary and tertiary fields and work life are also important. Throughout a teacher's career, the vision of professional development should stay positive.

The role of emotions is connected to professional identity in two ways: they shall be recognized, and the knowledge must be included in self-knowledge. Emotions can become either an obstacle of the promoter or the power of change, and in this way they reveal the multiple construction of teacher identity and the situationality of emotions (Kelchtermans, 2005). Emotions are indispensable even in rational action. Kasl and Yorks (2002) states that in order to be successful in learning and constructing one's identity, the teacher has to integrate four sub-areas of the psyche: affective, observation, cognitive and practical sub-areas, which come together in reflection. Heikkinen (2000, p. 10) sees a reflective teacher as a problem solver, not a technical rationalist ('bricoleur'). This is also how vocational teachers are to appear. As identity is incomplete and dynamic, narrative and socio-dynamic ways (Peavy, 1998) of completing the identities serve well in teachers' continuing education. Competence-based education will challenge both teacher and student personalities in coming years, preferably for their best. 


\section{References}

Clarke, L., \& Winch, C. 2007. Vocational education. International approaches, development and systems. London: Routledge.

Connell, R. (2009). Good teachers on dangerous ground: towards a new view of teacher quality and professionalism. Critical Studies in Education, 50(3), 213-229.

Cosnefroy, L., \& Buhot, E. (2013). Workplace learning impact: an analysis of French secondary-trainee teachers' perception of their professional development. Teachers and Teaching: theory and practice, $19(6), 679-694$.

De Brujin, E. (2012). Teaching in innovative vocational education in the Netherlands. Teachers and Teaching: theory and practice, 18(6), 637-653.

De Brujin, E. (2004). Changing pedagogic and didactic Approaches in vocational education in the Netherlands. From institutional interests to ambitions of students. European Journal of Vocational Training, 31(1), 27-37.

Eraut, M. (1994). Developing professional knowledge and competence. London: Falmer.

Eraut, M. (2004). Informal learning in the workplace. Studies in Continuing Education, 26, 248-303.

Eraut, M. (2007). Learning from other people in the workplace. Oxford Review of Education, 33(4), 403-422.

EU, European Union. (1999). The Bologna declaration of the European Ministers of Education convened in Bologna on 19, June 1999. Retrieved from http://eur-lex.europa.eu/browse/summaries.html Flores, M. A. (2004). The impact of school culture and leadership on new teachers' learning in the workplace. International Journal of Leadership in Education, 7, 1-22.

Flores, M. A., \& Day, C. (2006). Contexts which shape and reshape new teachers' identities: A multipleperspective study. Teaching and Teacher Education: theory and pratice, 22, 219-232.

FNBE (Finnish National Board of Education). (2014). Osaamisperustaisuus todeksi - askelmerkkejä koulutuksen järjestäjille [Making Competence-based Education Real - Steps for the Implication] Tutke 2 - toimeenpanon tukimateriaali. Oppaat ja käsikirjat 2014:8.

Fullan, M. (1993). Why Teachers Must Become Change Agents. Educational Leadership, 5o(6), 12-17. Harris, A. (2004). Distributed leadership and school improvement. Educational Management, Administration and Leadership, 31(1), 11-17.

Harris, A., \& Muijs, D. (2003). Teacher leadership improvement through empowerment? An overview of the literature. London: Sage.

Heikkinen HLT (2000). Opettajan ammatin olemusta etsimässä. [Searching for the Essence of a Teacher's Profession]. In K. Harra (Ed.), Opettajan professiosta [Of a Teacher's Profession] Vuosikirja no 1 (pp. 8-19). Helsinki: OKKA-säätiö.

Horvath, J. A., Sternberg, R. J., Forsythe, E. B., Bullis, R. C., Williams, W. M., \& Sweeney, P. J. (1996). Implicit theories of leadership practice. New York: Aera conference.

Heiskanen, N., \& Sairanen, P. (2013). The vocational teacher's changing role and identity in changing contexts. In K. Aaltonen, A. Isacsson, J. Laukia, \& L. Vanhanen-Nuutinen (Eds.), Practical Skills, 
Education and Development - Vocational Education and Training in Finland (pp. 128-141). Helsinki:

Haaga-Helia, The School of Vocational Teacher Education.

Kagan, D. M. (1992). Implications of research on teacher belief. Educational Psychologist, 27(1), 65-90.

Kasl, E., \& Yorks, L. (2002). Toward a theory and practice for whole-person learning: Reconceptualising experience and the role of affect. Adult Education Quarterley, 52, 76-192.

Kardos, S., \& Johnson, S. (2007). On their own and presumed expert: New teachers' experiences with their colleagues. Teachers College Record, 109, 2083-2106.

Kardos, S., Johnson, S., Peske,H., Kauffman, D., \& Liu, E. (2001). Counting on colleagues: New teachers encounter the professional cultures of their schools. Educational Administration Quarterley, 37, 250-300. Karjalainen, A., \& Nissilä, S-P. (2008/5). Designing and Piloting 60-Ects Credit Teacher Education Program for University Teachers. In K. Gerber (Ed.), Personal- und Organizationsentwicklung in Einrichtungen der Lehre und Forschung 5. Bielefelt: Universitatsverlag Webler.

Kelchtermans, G. (1993). Getting the story, understanding the lives: From career stories to teachers' professional development. Teaching and Teacher Education, 9(5), 443-456.

Kelchtermans, G. (1996). Teacher vulnerability. Understanding its moral and political roots. Cambridge Journal of Education, 26, 307-323.

Kelchtermans, G. (2005). Teachers' emotions in education reforms: Self-understanding, vulnerable commitment and micropolitical literacy. Teaching and Teacher Education, 18, 105-120.

Kelchtermans, G. (2009). Who I am in how I teach is the message: Self-understanding, vulnerability and reflection. Teachers and Teaching: Theory and Practice, 15, 257-272.

Kelly, G. A. (1955). The psychology of personal constructs (Vols. 1\&2). New York: W.M. Norton. Korthagen, F. (2004). In search of the essence of a good teacher: Towards a more holistic approach in teacher education. Teaching and Teacher Education, 20, 77-97.

Koster, B., Dengerink, J., Korthagen, F., \& Lunenberg, M. (2008). Teacher educators working on their own professional development: Goals, activities and outcomes of a project for the professional development of teacher educators. Teachers and Teaching: Theory and Practice, 14, 567-587.

Krathwohl, D. (2002). A Revision of Bloom's Taxonomy: An Overview. Theory into Practice, 41(4, Autumn 2002), 214-218.

Laajala, T. (2015). Diskurssianalyyttinen tutkimus ammattikorkeakoulun opetussuunnitelman

kehittämisprosessista [A discourse-analytic research on the curriculum development process in a university of applied sciences]. Rovaniemi: The University of Lapland.

Lave, J., \& Wenger, E. (1991). Situated Learning: Legitimate peripheral participation. New York, NY:

Cambridge University Press.

Leithwood, K., \& Riehl, C. (2003). What do we already know about successful leadership? Paper presented in AERA, January 2003, Temple University.

Lieberman, A., \& Pointer Mace, D. H. (2009). The role of "accomplished teachers" in professional learning communities: uncovering practice and enabling leadership. Teachers and Teaching: theory and practice, 15(4), 459-470.

Little, J. (1996). The emotional contours and career trajectories of (disappointed) reform enthusiasts. 
Cambridge Journal of Education, 26, 345-359.

Länsitie, J., \& Kepanen, P. (2014). Competence-based learning paths in vocational teachers' pedagogical program. A paper presented in ATEE Conference in Braga, Portugal in 2014.

Mitchell, C., \& Sackney, L. (2000). Profound improvement: Building capacity for a learning community.

Lisse: Swets and Zeitlinger.

Nias, J. (1989). Teaching and the self. In M. L Holly \& C. S. McLoughlin (Eds.), Perspective on teacher professional development (pp. 151-171). London: Falmer Press.

Nissilä, S-P. (2013). The vocational teacher's changing role and identity in changing contexts. In K. Aaltonen, A. Isacsson, J. Laukia, \& L. Vanhanen-Nuutinen (Eds.), Practical Skills, Education and Development - Vocational Education and Training in Finland. Helsinki: Haaga-Helia, The School of Vocational Teacher Education.

Nissilä, S-P. (2006). Dynamic Dialogue in Learning and Teaching. Towards Transformation in Vocational Teacher Education. Acta Universitatis Tamperensis 1179.

Pantic, N., \& Wubbels, T. (2010). Teacher competencies as a basis for teacher education - View of Serbian teachers and teacher educators. Teaching and Teacher Education, 26, 694-703.

Peavy, V. (1998). Socio-dynamic Counselling. A constructivist perspective. Victoria BC Canada: Trafford Publishing.

Spillane, J., Halverson, R., \& Diamond, J. (2001). Investigating School Leadership Practice: A Distributed Perspective. American Educational Researcher, 3o(3), 23-28.

Struyven, K., \& De Meyst, M. (2010). Competence-based teacher education: Illusion or reality? An assessment of the implementation status in Flanders from teachers' and students' point of view.

Teaching and Teacher Education, 26, 1495-1510.

Tynjälä, P. (2008). Perspectives into learning at the workplace. Educational Research Review, 3, 130-154.

Wenger, E. (1998). Communities of Practice: Learning, meaning and identity. Cambridge: Cambridge University Press.

Whitty, G., \& Wilmott, E. (1991). Competence-based education: Approaches and issues. Cambridge Journal of Education, 21, 309-319.

Zembylas, M. (2003). Interrogating teacher identity: emotions, resistance, and self-formation.

Educational Theory, 53, 197-127.

\section{Biographical note}

SÄde-Pirkкo Nissilä, PhD, MA, Principal Lecturer (emerita), in Oulu University of Applied Sciences, the School of Vocational Teacher Education, has earlier been English and Latin language lecturer in the sixth form and the lecturer of foreign language didactics in the University of Oulu. At the moment she concentrates on general and adult vocational pedagogy and educates peer group mentors for teachers and directors of education. Her interests 
are the phenomena of learning, teachers' professional growth and the development of teacher identities. Her doctoral thesis dealt with the professional growth of academic and and 3 rd career vocational teachers.

E-mail: sade-pirkko.nissila@oamk.fi

Asko Karjalainen, $\mathrm{PhD}$, the director of the School of Vocational Teacher Education at Oulu University of Applied Sciences specializes in teaching development issues of higher education. The main themes of research have been assessment of learning, innovative teaching methods, curriculum design and issues concerning development oriented methods of evaluation and quality assurance. He is one of the creators of the Finnish network for developing instruction and learning in higher education (Peda-forum). Currently he is involved in developing vocational pedagogy and teacher education and contributing actively to competence based curriculum and study design in teacher education. He has established special virtual teaching laboratory for teacher education (STUDIO) and promotes new teaching media, especially videos in teaching. He produces, writes and directs educational movies and gives consultation.

E-mail: asko.karjalainen@oamk.fi

MarJa Koukkari, PhD, MEd, Principal Lecturer in Oulu University of Applied Sciences, the School of Vocational Teacher Education has been a lecturer in vocational tertiary education of social and health sciences and acted as a specialist in rehabilitation. In her present task she is responsible for the planning, implementation and development of vocational pedagogical studies. She teaches also in vocational special teacher degree courses. She is interested in supporting the self-management skills of vocational and special education teachers as well as promoting well-being at work in solutions and human resource-based ways. E-mail: marja.koukkari@oamk.fi

Pirkкo Kepanen, MEd, Lecturer in Oulu University of Applied Sciences, the School of Vocational Teacher Education, is a special education teacher. At the moment she works as a teacher in competence-based vocational special teacher education. Her interests are demonstration of pedagogical competence in teacher education, self-assessment, recognition of previously acquired skills and inclusive education in vocational schools in Finland. She is preparing a doctoral thesis on the students' growth in the issues mentioned above.

Email: pirkko.kepanen@oamk.fi 